\title{
Exploring the Development of College English General Education Based on the Perspective of Supply Side Reform
}

\author{
Tao Yeqing \\ College of Foreign Languages, Shaoguan University, Guangdong, China, 512005
}

Keywords: supply side; college English; teaching reform; internal motivation

\begin{abstract}
With the increasing frequency of economic and trade exchanges between China and many countries in the world, the demand for compound talents in the society has become more prominent. Especially the demand for English-language composite foreign language talents has become more urgent. College English education also faces the trend of school transformation. . To this end, how to cope with the challenges of the new situation and adapt to the transformation of the university in the talent training mode, the author first analyzes the current situation of college English teaching, and proposes from the supply side perspective what is the university English transition in the university. Suggestions and strategies for the reform of college English teaching.
\end{abstract}

\section{Introduction}

After years of teaching reform, college English teaching in China has partially realized computer-based modern education teaching modes, such as computer multimedia teaching, flipping classrooms, MOOC (Mu class) and other new English teaching methods; The "Duck-cramming" traditional teaching mode is conducive to the active classroom atmosphere, increasing the amount of classroom information and the diversity of language teaching modes. However, there are still some problems in English education and teaching in China, the most prominent of which is 'duty time and inefficiency in dumb English and English learning [1]. It is mainly reflected in the employer's employer's ability to reflect the students' oral English, translation and writing skills. That is to say, the society's thirst for talents training in colleges and universities has not really responded and satisfied.

\section{Development Goals}

To this end, the author believes that the transformation of some colleges and universities will inevitably require the transformation of university English teaching concepts, teaching modes, methods and means, management, etc. The deepening of college English teaching reform must also meet the talent training objectives of compound applied foreign language talents. The requirements to meet the needs of the demand side (ie social employer) type of talent, to the greatest extent to serve the community. 


\section{Current situation of supply side of college English teaching in local colleges and universities}

\subsection{The teacher's task is heavy and the classroom teaching efficiency is not high}

With the expansion of colleges and universities in recent years, college English generally assumes the teaching tasks of many large classes. Teachers are busy preparing lessons, classroom teaching, reviewing student homework and counseling, which makes them physically and mentally exhausted. As a result, the structure of English teachers' professional knowledge is aging, lacking systematic and professional, and the overall knowledge structure is single. Secondly, English teachers have a low level of general academic titles. In addition, the large amount of teaching work of teachers makes the contradiction between teaching and scientific research prominent, and the research ability is weak, especially the high-level scientific research results are difficult, especially young teachers.

\subsection{Students have long study time, but their enthusiasm and initiative are not high}

The third-party teaching evaluation that has been carried out by the author's school for many years, that is, the analysis of the data of the Max Report, the students' English basics are uneven, and the students with poor English foundation are mainly from rural families (concentrated in grammar, listening and speaking). Generally, it is poor, lacking the self-learning awareness and self-learning habits of English learning. The general education model clearly cannot meet and adapt to the needs of students' English differentiation and English individualized learning.

\subsection{Local universities, especially comprehensive colleges, lack policy on college English teachers}

The orientation of English university teachers' career development is vague and the development path is difficult and long. For English teachers who are engaged in college English, they have almost undertaken the teaching tasks of public English in the first and second grades of the whole school. There are many classes and heavy teaching tasks. There is very little free time to take care of their career planning and development. Not only that, English There are very few opportunities for teachers to participate in training and training at home and abroad. The management department's humanistic care for English teachers is not in place, which has affected the enthusiasm and enthusiasm of English teachers. Examples of teaching arrangements for English general education courses.

\begin{tabular}{|c|c|c|}
\hline \multicolumn{3}{|l|}{ Digital classroom } \\
\hline Device placement & Classroom names & Device contents \\
\hline $\begin{array}{l}\text { Teaching and research } \\
\text { building }\end{array}$ & T0-505 & $\begin{array}{l}\text { Computer desk } \\
\text { Electric screen - } \\
\text { Computer - Projector V } \\
\text { Microphone - Mixing } \\
\text { machine - Recording and } \\
\text { playback Whiteboard }\end{array}$ \\
\hline $\begin{array}{l}\text { Teaching and research } \\
\text { building }\end{array}$ & D3-502 & $\begin{array}{l}\text { Computer desk } \\
\text { Electric screen } \\
\text { Computer - Projector - } \\
\text { Microphone - Mixing } \\
\text { machine - Recording and } \\
\text { playback blackboard }\end{array}$ \\
\hline
\end{tabular}

Fig.1 Examples of teaching arrangements for English general education courses 


\section{Reform strategy of college English supply side in local colleges and universities}

Based on the actual situation of the supply side of college English teaching, the reform of the supply side of college English focuses on adjusting the supply structure of English teaching and learning, and expects to stimulate students' internal motivation to cultivate students' English application ability. The author believes that the following strategies can be used to cultivate College students' comprehensive language ability and intercultural communication ability.

\subsection{Promote the new teaching concept of "knowing" and "going"}

While paying attention to the basic knowledge of English at the basic stage and the general education of basic skills, we should also highlight the importance of applying what we have learned in terms of teaching objectives, curriculum, and evaluation system, and we will use "knowledge" and "walking" throughout this In the process of teaching.

\subsection{Improve the business level}

In recent years, with the continuous advancement of economic globalization and the deepening of China's reform and opening up, the demand for English in various professional fields has also increased. The advantages of general English have been cut, and the demand for professional and workplace English has far exceeded. Know English. The focus of most college English teaching is still inclined to EGP teaching, ignoring the need for English learners of English learners. Obviously, such teaching ideas are obviously contrary to the future career development of students. Professor Liu Runqing believes that "future English teaching is more and more integrated with a certain aspect of professional knowledge or a certain subject, and specialized English teaching will become the mainstream of English teaching in the 21st century" [2]. In order to meet the requirements of the comprehensive and applied talents training objectives of colleges and universities, and to meet the needs of the development of the situation, the professional development of college English teachers should still focus on professional English, taking into account the basic knowledge of one or two professional courses to meet the future university. The practical needs of English Teaching General (EGP) and Special Purpose English (ESP) teaching.

\subsection{Achieve a model for college English curriculum}

Local colleges and universities can carry out staged English teaching according to the setting of teaching objectives in the new era. Among them, the first stage is the basic stage, which mainly carries out EGP teaching, aiming at cultivating students' basic knowledge and basic skills of English language and strengthening the content of weak teaching. If students' listening and speaking ability is generally weak, they should carry out intensive teaching and training in a targeted manner. Students' English communication skills. The second stage is the EGP teaching phase. Teachers should carry out curriculum design according to the students' professional, and offer relevant ESP elective courses. Through professional English learning, they can play the purpose of enlightenment teaching. In this way, ESP teaching is not only conducive to stimulating students' interest in English learning, but also paving the way for later professional courses. "The new teaching mode should be supported by modern information technology, especially network technology, so that English teaching is not limited by time and place, and it is developing towards personalized learning and autonomous learning" [3]. Therefore, English teachers can also carry out modular teaching of individual skills such as listening, speaking, writing and reading according to the characteristics of students' learning. 
The development of high-level language application ability to meet the needs of high-level students with top-notch innovation potential to participate in school, provincial, national and even international academic exchanges, to meet the needs of students' individualized learning, is conducive to the development of students' individuality and Lay a solid foundation for self-directed learning and lifelong learning.

\subsection{Increase the construction of the language}

The advanced language lab and the English self-learning platform construction are the necessary venues and facilities for the students' English application ability training. Without these resources, the students' lack of listening and speaking ability will be lack of dependence, which will seriously affect the normal English teaching order and student language. The increase in application capabilities will be greatly affected. Therefore, the construction of language teaching equipment, especially the construction of autonomous learning platform for college English network, will provide online English learning resources for teachers and students, and diversify and modernize English teaching models[4].English language teaching platform arrangement mode is as follows.

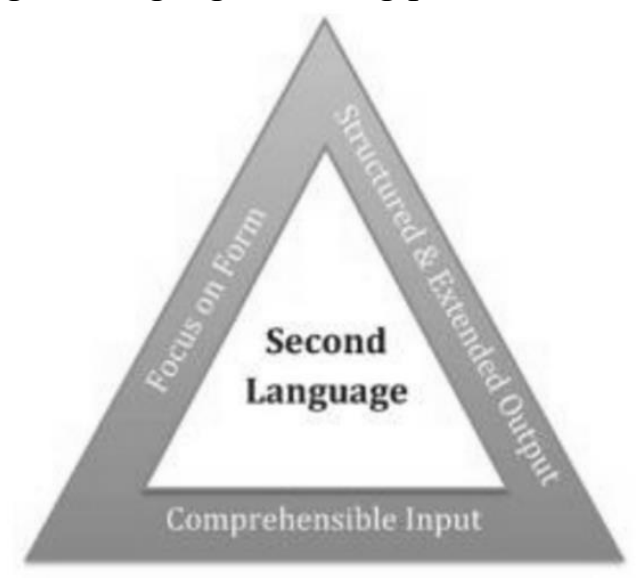

Fig.2 English language teaching platform arrangement mode

\subsection{Enrich the second class and vigorously stimulate students' interest in English learning}

The development of the second classroom of College English can not only break the long-term single teaching mode, but also make full use of extracurricular practice activities to form a three-dimensional teaching method of college English, so that English learning can be integrated into the daily life of students, which is more conducive to English language. Learned. The second classroom form should be diversified, such as organizing students to carry out English Corner, foreign teacher series lectures, speech contests, drama performances, style contests, English song singing competitions, English film dubbing competitions, English Culture Festival, English Summer Camp, English Drama Festival, etc. The development of these activities not only enriches students' extracurricular life, but also helps students to improve their English comprehensive application ability and humanities literacy and stimulate students' interest in learning English.

\section{Summary}

In short, the author analyzes the problems existing in various aspects of college English teaching by expounding the current supply situation of college English in local universities, and proposes the transition stage of local universities from the perspective of social demand side and college English 
teaching supply side. How to make suggestions and strategies for the transformation of college English teaching concepts, the presentation of curriculum settings, and how the external environment of teaching meets and supports the needs of college English teaching in transition. The reform of college English is in the ascendant, especially in the era of Internet plus, the ways of learning English and the resources available for students to learn and share are more diverse. To make the quality of college English classroom teaching high, students have good learning experience, they must start from the supply side perspective. To understand the needs of students and the social requirements of college students' English proficiency, in order to optimize and upgrade teachers' business knowledge, supplement professional knowledge, and stimulate students' internal motivation, and train students to listen, speak, read, write and translate English. Language application skills, ESP English reading and translation skills.

\section{References}

[1] Ann Hodgson, Ken Spours. Rethinking general education in the English upper secondary system[J]. London Review of Education,2011,9(2).

[2] Maria-Miruna Ciocoi-Pop. A General Overview Of English As A Foreign Language In The Contemporary Romanian Higher Education[J]. International conference KNOWLEDGE-BASED ORGANIZATION,2015,21(2).

[3] 52. Rumlich, Dominik. 2016. Evaluating Bilingual Education in Germany: CLIL Students' General English Proficiency, EFL Self-Concept and Interest. Frankfurt am Main: Lang, 582 pp.[J]. English and American Studies in German,2017,6(1).

[4] Zhang Yan, Wu Ping. College-English-Teaching Reform Under the Perspective of General Education[M].Springer New York:2013-06-15. 